\title{
ПРОФЕСІЙНО-КОМУНІКАТИВНА КУЛЬТУРА МАЙБУТНІХ ЛІКАРІВ КРІЗЬ ПРИЗМУ ФАХОВОЇ ОСВІТИ
}

\author{
I. I. Vorona' ${ }^{1}$, H. Ya. Kitura' ${ }^{1}$, O. A. Makovska² \\ ${ }^{1}$ I. Horbachevsky Ternopil National Medical University \\ ${ }^{2}$ Kyiv National University of Technologies and Design \\ PROFESSIONAL AND COMMUNICATIVE CULTURE OF FUTURE \\ DOCTORS IN THE LIGHT OF PROFESSIONAL EDUCATION
}

\begin{abstract}
Анотація. Стаття присвячена обгрунтуванню основних концептів професійно-комунікативної культури фахівців медичного профілю в контексті фахової освіти. З'ясовано суть професійної культури, що є важливою складовою професіограми майбутнього працівника охорони здоров'я. Наголошується, що формування професійно-комунікативної культури студента-медика $\epsilon$ невід'ємним аспектом професійно орієнтованого навчання у медичному ЗВО і здійснюється шляхом опанування особливостей фахового спілкування. Увага акцентується на необхідності аналізу різноманітних методик та підходів щодо формування професійно-комунікативної культури у студентів із різним рівнем знань та навичок. Розглядаються питання змістового наповнення та ефективності процесу формування фахової компетентності, відбору навчального матеріалу, розвитку комунікативного компонента в процесі оволодіння студентом основами культури спілкування. Охарактеризовано ефективні шляхи формування повноцінної фахової комунікативної діяльності, розглянуто рівні професійної культури майбутніх фахівців, якими є професійна грамотність, професійна компетентність, мотиваційно-ціннісний та емоційно-чуттєвий компоненти; наголошено на необхідності засвоєння лексики для правильного оформлення висловлювання; окреслено основні домінанти комунікативної культури. Запропоновано констатувати професійно-комунікативну культуру майбутніх лікарів як складне динамічне особистісне утворення, що охоплює систему гуманістичних та професійних цінностей, мовленнєвих та етичних знань, комунікативних умінь і якостей, зразків поведінки, норм і правил здійснення професійної комунікативної діяльності, котрі пов’язані зі специфікою професії і забезпечують високу ефективність професійної комунікації лікарів.
\end{abstract}

Ключові слова: професійно-комунікативна культура; фахова освіта; професійно-комунікативні вміння; спілкування.

Abstract. The article deals with interpretation of principal concepts of medical specialists' professional and communicative culture in the context of professional education. The essence of professional culture, which is an important component of the professional profile of a future healthcare worker is clarified. It is emphasized that the formation of professional and communicative culture of a medical student is an integral aspect of professionally oriented education in medical institution of higher education and is carried out by mastering the features of professional communication. Emphasis is placed on the need to analyze various methods and approaches to the formation of professional and communicative culture in students with different levels of knowledge and skills. The issues of content and efficiency of the process of professional communicative competence formation, selection of educational material, development of communicative component in the process of students' mastering the basics of communication culture are examined. The effective ways of formation of valuable professional activity are characterized; the levels of professional culture of future specialists, which are professional literacy, professional competence, motivational-valuable and emotional-sensory components are observed; the need to learn vocabulary for the correct formulation of the statement is emphasized; the main dominants of communicative culture are outlined. It is proposed to state the professional and communicative culture of future doctors as a complex and dynamic personal essence that embraces a system of humanistic and professional values, speech and ethical knowledge, communicative skills and qualities, patterns of behaviour, norms and rules of professional communication activities that are related to the peculiarities of profession and provide high efficiency of professional communication of doctors.

Key words: professional and communicative culture; professional education; professional and communicative skills; communication.

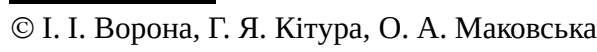


Вступ. Сучасні тенденції розвитку медицини та медичної освіти висувають нові вимоги до якості професійної підготовки майбутніх лікарів. Медична сфера в Україні потребує добре підготовлених фахівців, що володіють належним рівнем готовності до професійної комунікації. Професійна освіта поступово перестає бути виключно процесом підготовки людини до професійної діяльності. Ї̈̈ призначення все більше полягає у виконанні сукупності гуманістичних завдань, формуванні й розвиткові особистості, вихованні загальної культури, духовності, морально-етичних принципів і тверджень. Це означає, що сьогодні суспільство вимагає від професійної освіти ефективної підготовки людини до успішного морального життя й професійної діяльності у складних та динамічних умовах сучасного світу [7].

Успішність фахової діяльності значною мірою залежить від того, як індивідуальні психологічні якості спеціаліста відповідають вимогам профеciї, як особистість сприймає традиції, норми та правила поведінки в певній професійній сфері. Це дає підстави стверджувати, що шляхи формування і розвитку особистості та становлення її професійних якостей є важливими у професійно-комунікативній культурі.

Вивченню фахової культури майбутніх спеціалістів різних професій присвячені наукові праці Г. А. Балла, М. Г. Бойко, А. Г. Видри, А. В. Винеславської, Н. І. Волошко, Е. А. Климова, А. В. Просфори, В. В. Рибалки. Питання професійної культури знайшло відображення у наукових роботах В. П. Андрущенка, С. У. Гончаренка, І. А. Зязюна, В. Г. Кременя, Н. Г. Ничкало, В. Ф. Орлова, С. О. Сисоєвої та інших.

Фундаментальним концептом нашого дослідження $є$ поняття «культура». Термін «культура» походить від латинського “cultura” - обробка, виховання, освіта. Одне із загальних визначень феномена культури - це сукупний результат продуктивної діяльності людей, а також сам процес творення матеріальних і духовних цінностей. Водночас професійна культура - це цілісна, складна ієрархічна система професійної структури особистості, що складається і функціонує у взаємодії двох форм: об’єктивної (мобікультурні об’єкти та реалії) та суб’єктивної (відбиток культури у свідомості).

У понятті «професіоналізм» відображається ступінь оволодіння людиною психологічною структурою професійної діяльності, яка відповідає існуючим у суспільстві стандартам й об’ єктивним вимогам. Професіоналізм людини це не лише досягнення нею високих виробничих показників, а й особливості її професійної мотивації, ціннісних орієнтацій, сутність праці для самої людини.

У культурологічному словнику зазначено: «Професійна культура характеризує рівень і якість професійної діяльності, які залежать від соціальноекономічного стану суспільства й сумлінності в оволодінні певними знаннями, навичками конкретної професії та їх практичному використанні» [5, c. 173].

На думку В. А. Семиченко, зміст процесу формування професійної культури полягає в тому, щоб допомогти майбутньому спеціалісту зрозуміти сутність обраної професії, її вимоги до виконання, цілі, зміст і функції професійної діяльності, можливі індивідуальні стратегї̈ виконання професійних обов'язків, специфіку фахової майстерності та шляхи оволодіння нею, прийоми творчої адаптації до змісту та структури професійної діяльності [9, с. 114].

Ефективними шляхами формування професійної культури майбутніх спеціалістів є організація цілісного навчально-виховного процесу і його орієнтація на розвиток усіх компонентів професійної культури; структурування змісту професійної підготовки на основі нерозривного зв'язку із засвоєнням соціально-гуманітарних та професійно-орієнтованих предметів; формування професійних навичок. Серед важливих якостей високоефективної професійної підготовки студентів виділяють основні складові рівні професійної культури майбутнього спеціаліста, якими є: професійна грамотність, професійна компетентність, мотиваційно-ціннісний та емоційно-чуттєвий компоненти. Необхідно враховувати, що ці компоненти професійної культури в цілому взаємопов'язані, а міжкомпонентні зв’язки взаємообумовлені.

Рівень професійної культури майбутніх спеціалістів знаходиться у прямій залежності від рівня їх професійної майстерності. Студент із низьким рівнем сформованості професійної культури є непідготовленим до практичного виконання своїх професійних обов'язків, оскільки високий рівень фахової культури співвідноситься з високим рівнем професійної майстерності і сприяє підвищенню фахових якостей спеціаліста та його майбутньої конкурентоспроможності.

Мета статті. Культура медичного фахівця поєднує культуру поведінки, комунікативну культуру, культуру обслуговування пацієнтів, організаційну 
культуру тощо. Очевидно, що ці елементи пов’ язані з професійною етикою, тому вважаємо за доцільне виокремити метою нашого дослідження професійно-комунікативну культуру медичного фахівця крізь призму фахової освіти.

Теоретична частина. Професійне становлення студента медичного закладу вищої освіти у процесі фахової підготовки вимагає від нього складної напруженої творчої роботи над розвитком власної особистості, подолання себе, вибору одних можливостей і відмови від інших. Майбутній спеціаліст має досягнути, в першу чергу, найвищого рівня розвитку мистецтва жити - особливого вміння і високої майстерності у творчій побудові свого життя, що базується на глибоких знаннях, розвиненій самосвідомості та володінні системою засобів, методів, технологій програмування та конструювання як індивідуально-особистісного життєвого проекту.

Соціальні дослідження та практика свідчать, що до змісту загальної культури майбутнього медичного працівника належать життєві установки та пріоритети загальнолюдських цінностей - істини любові, добра, краси, свободи тощо. Ядром загальної культури особистості є освіченість і вихованість у їхній гармонійній єдності. Показником загального розвитку медика $є$ рівень його пізнавальних процесів: мислення, уваги, сприйняття, пам'яті, уявлення. Результативність професійної медичної діяльності багато в чому визначається також і ступенем розвитку емоційно-вольової сфери, багатством і «дисципліною» почуттів, тобто вмінням стримувати себе, не піддаватися настрою. Такі якості, як енергійність, товариськість, почуття гумору, сприяють успішному вирішенню дидактичних виховних завдань.

У своїх дослідженнях Ю. Орел-Халік зазначає, що підготовка майбутніх фахівців-медиків до належного виконання ними професійних завдань передбачає володіння культурою спілкування на високому рівні. Культура професійного спілкування стає однією з найважливіших проблем у підготовці майбутніх фахівців [8].

У розумінні комунікативної культури студентів медичних закладів вищої освіти Н. Касевич вбачає сукупність професійних якостей, моральних цінностей і комунікативних умінь майбутнього лікаря, що реалізуються під час спілкування. До професійно-комунікативних якостей науковець відносить: професійну ерудицію, спостережливість, здатність до логічного осмислення діагностичних і лікувальних маніпуляцій, тактовність, обачність; моральними цінностями вважає: толерантність, чуйність, ввічливість, привітність, співчуття, доброчинність; комунікативними уміннями - вміння спілкуватися з пацієнтами, рідними пацієнта, колегами, підлеглими та адміністрацією [3, с. 19].

Професійна лікарська діяльність має ряд специфічних особливостей, та її успішність визначається не тільки професійними знаннями і навичками, а й уміннями реалізувати їх у своїй діяльності. Праця лікаря характеризується тим, що істотне місце в ній займає значна кількість міжособистісних контактів. У діяльності лікаря комунікативна компетентність обумовлює ефективність спілкування з пацієнтами, їхніми родичами та колегами. Це така комунікативна взаємодія, яка сприяє успішному вирішенню проблем учасниками комунікації; забезпечує досягнення цілей спілкування з оптимальними витратами і приводить до досягнення взаєморозуміння між партнерами по спілкуванню.

Оволодіння мистецтвом слова є важливою умовою успішного впливу на пацієнтів, потужним засобом профілактики та лікування захворювань. Відомий давньогрецький учений Гіппократ вважав, що супутником лікаря у професійній діяльності має бути ввічливість, оскільки суворість сприяє виникненню бар’єрів між лікарем та пацієнтом [6].

Характеризуючи інтегральну медико-психологічну модель особистості сімейного лікаря, І. Вітенко підкреслює, що успіх встановлення позитивного комунікативного контакту з пацієнтом грунтується на наявності у фахівця медика таких моральних якостей, як співчуття, працелюбність, увага, скромність, доброзичливість, пунктуальність, чесність, принциповість, гідність [2, с. 24]. М. Філоненко комунікативними якостями лікаря визначає ввічливість, авторитет, готовність допомогти, повагу до інших, тактовність, уважність, комунікабельність, спостережливість [10, с. 132].

Найбільш важливими серед комунікативних якостей майбутніх лікарів О. Корж вважає гнучкість спілкування, емпатійність та рефлексивність, від рівня сформованості яких залежить характер стосунків між лікарем і пацієнтом. Гнучкість у спілкуванні науковець співвідносить із майстерним володінням мовою, здатністю до самовираження у спілкуванні залежно від ситуації. Емпатійність, як зазначає автор, забезпечує конструктивну взаємодію між лікарем та пацієнтом, сприяє позитивним змінам у формуванні особистості. Рефлексія як процес осмислення людиною її відносин із соці- 
альним світом є джерелом внутрішнього досвіду і засобом самопізнання, універсальним механізмом саморозвитку, необхідною основою особистісного зростання [4].

На нашу думку, професійно-комунікативна компетентність майбутніх медиків включає: професійні та спеціальні знання, уміння, навички; здатність функціонувати в соціумі з урахуванням позицій інших людей; можливість вступати до комунікації з метою бути зрозумілим; здатність вільно володіти мовою конструктивного діалогу; вміння правильно й доступно формулювати професійну думку та суспільно-громадську позицію, особистісне самовираження медичного працівника.

Професія лікаря - лінгвоактивна професія. Слово або мова лікаря має дуже важливе значення. Про необхідність вдосконалення мови засобом цілеспрямованого навчання писали ще великі мудреці Стародавньої Греції та Риму. Таланту цілющого слова лікаря надавали великого значення з глибокої давнини. Академік О. Білібін писав, що вирішальною й визначною якістю клінічної роботи є не методика дослідження, а культура власної особистості лікаря [1, с. 53].

Ми трактуємо професійно-комунікативну культуру майбутніх лікарів як складне динамічне особистісне утворення, що охоплює систему гуманістичних та професійних цінностей, мовленнєвих та етичних знань, комунікативних умінь і якостей, зразків поведінки, норм і правил здійснення професійної мовленнєвої діяльності, котрі пов’язані зі специфікою професії і забезпечують високу ефективність професійної комунікації лікарів. Підкреслимо, що цінності, на нашу думку, займають особливо важливе місце у структурі цього утворення у зв’язку з широкою розповсюдженістю аксіологічного тлумачення поняття «культура» як сукупності усіх створених людьми цінностей. Систему цінностей, що відіграє роль стійких орієнтирів професійної діяльності, ми розглядаємо як основу професійно-комунікативної культури майбутніх лікарів.

За специфікою своєї діяльності лікарі мають демонструвати найвище виявлення людяності, чуйності, терпимості, відповідальності та турботи про іншу людину, а професійна комунікація лікарів, як основна частина їх професійної діяльності, повинна також керуватися принципами гуманізму та милосердя, ціннісні орієнтації, що формують основу професійно-комунікативної культури майбутніх медиків, на нашу думку, повинні грунтуватися перш за все на гуманістичних цінностях. Під гуманістични- ми цінностями розуміють систему значущих ідей, норм, принципів та ідеалів суспільної та особистої діяльності, які, виступаючи зразками добра, людяності, милосердя, визначають поведінку людини та покликані формувати усвідомлене, позитивне ставлення особистості до навколишнього соціуму. Гуманістичними цінностями, що відіграють ключову роль у формуванні професійно-комунікативної культури майбутніх лікарів, ми вважаємо систему базових гуманістичних цінностей, яка включає життя, добро, любов до ближнього, співчуття, справедливість, совість, повагу до людської гідності. Сформованість гуманістичних та професійних ціннісних орієнтацій майбутніх лікарів $\epsilon$ необхідною умовою високого рівня розвитку їх професійно-комунікативної культури.

Слід зазначити, що під час навчання студентів у закладах вищої освіти такі види діяльності, як робота з інформацією та науково-дослідна робота, також безпосередньо пов’язані з комунікативною підготовкою майбутніх лікарів. Тому ще однією особливістю підготовки майбутніх лікарів до професійної іншомовної комунікації $є$ використання під час занять інноваційних форм і методів навчання, зокрема ділових, рольових ігор, семінарів-дискусій, ситуаційних вправ (кейси), інтерактивних форм і методів проведення занять на основі діалогічно-полілогічної взаємодії (навчальні тренінги, дидактичні ігри, диспути, дискусії тощо), а також поширення досвіду використання сучасних методик навчання.

Суттєвим у процесі навчання студентів $є$ моделювання феноменів професійної іншомовної комунікації, аналіз комунікативних ситуацій. Тому професійно-комунікативними вміннями студентів-медиків, необхідними для їхньої повноцінної фахової діяльності в майбутньому, є:

- уміння встановлювати психологічний контакт із людьми, забезпечувати взаємини, необхідні для спільної діяльності у лікуванні;

- мовленнєві вміння (здатність ефективно використовувати загальновживану лексику та спеціальну термінологію і професійні слова з метою забезпечення успішності мовленнєвого акту, ознаками якої є змістовність, доступність, зрозумілість, доречність, різноманітність, виразність, естетичність) [11].

Висновки та перспективи подальших досліджень. Отже, грунтуючись на результатах вітчизняних та зарубіжних досліджень, можна зробити висновок, що комунікативна культура - це властивість 
iї носія, яка дозволяє йому відтворювати засвоєні ним знання, цінності, моральні й етичні норми, проявляючи індивідуальні та особистісні якості, досягати конгруентного спілкування, а саме: репрезентування власних думок, ефективного сприйняття, розуміння партнерів по спілкуванню, їх взаємодії і взаємовпливу, використовуючи вербальні та невербальні комунікативні уміння й навички.

Професійно-комунікативна культура $є$ невід’ємною частиною професійної діяльності індивіда, бо саме вона відображає особистісні якості та властивості фахівця, за допомогою яких він самостійно й ефективно реалізовує завдання професійної діяльності, які пов’язані з діями інших людей. Сформованість професійно-комунікативної культури у фахівця свідчить про його теоретичну та практичну готовність до здійснення ефективної професійної діяльності, що вимагає встановлення регулярних комунікативних контактів з іншими співробітниками. У щоденному спілкуванні висловлені думки, звернені до інших людей, демонструють мовленнєву характеристику медичного фахівця. 3 мовцем, у якого багата й колоритна мова, легко спілкуватися, тому майбутньому лікарю потрібно працювати над своїм мовленням.

Розглянуті теоретичні аспекти необхідні для формування професійно-комунікативної культури майбутніх лікарів крізь оптику фахової освіти, безумовно, не вичерпують глибину форм і методів. Багато питань удосконалення та впровадження концептів професійно-комунікативної культури в систему вищої освіти чекають своєї розробки як у теоретичній, так і в практичній площинах.

інституту ім. Тараса Шевченка. Серія «Педагогічні науки». - 2010. - № 1 (3). - С. 195-202.

7. Маража I. О. Роль педагогіки в клінічній практиці лікаря / I. О. Маража, I. В. Жулкевич // Медична освіта. 2021. - № 2. - C. 94-99. DOI https://doi.org/10.11603/ me.2414-5998.2021.2.12058.

8. Орел-Халік Ю. В. Формування культури професійного спілкування майбутніх лікарів засобами іноземної мови [Електронний ресурс] / Ю. В. Орел-Халік. - Режим доступу : www.nbuv.gov.ua/portal/.../P2312_59.pdf.

9. Семиченко В. А. Пути повышения изучения психологии / В. А. Семиченко. - К. : Магистр-S, 1997. - 124 с.

10. Філоненко М. М. Психологія спілкування : підручник / М. М. Філоненко. - К. : Центр учбової літератури, 2008. - 224 c.

11. Vorona I. I. Terminological vocabulary of communicative culture in the paradigm of foreign language competence / I. I. Vorona, H. Ya. Kitura // Медична освіта. 2021. - № 1 (91). - C. 98-105.

\section{References}

1. Bilibin, A.F. (2010). Kultura myishleniya vracha [The culture of the doctor's thinking]. Zdravoohranenie - Health Care, 7, 46-53 [in Russian].

2. Vitenko, I.S. (2012). Intehralna medyko-psykholohichna model simeinoho likaria [Integral medical and psychological model of the family doctor]. Medytsynskaia psykholohyiaMedical Psychology, 7(3), 22-25 [in Ukrainian].

3. Kasevych, N.M. (2009). Medsestrynska etyka $i$ deontolohiia: pidruchnyk [Nursing ethics and deontology: textbook]. Kyiv: Instytut kulturolohii AMU [in Ukrainian].

4. Korzh, O.Yu. (2011). Komunikatyvni yakosti maibutnikh likariv [Communicative qualities of future

doctors]. Naukovyi visnyk Donbasu - Scientific Bulletin of Donbas, 3. Retrieved from : http://nbuv.gov.ua/j-pdf/ nvd_2011_3_11.pdf [in Ukrainian].

5. Korinnyi, M.M., \& Shevchenko, V.F. (2003). Korotkyi entsyklopedychnyi slovnyk z kultury [Short encyclopedic vocabulary of culture]. Kyiv : Ukraina [in Ukrainian].

6. Kubitskyi, S.O., \& Nedilka, N.V. (2010). Osoblyvosti profesiinoi komunikatyvnoi vzaiemodii maibutnikh medpratsivnykiv [Special features of the professional communicative relations of future medical professionals]. Zbirnyk naukovykh prats Kremenetskoho oblasnoho humanitarno-pedahohichnoho instytutu im. Tarasa 
Shevchenka. Seriya «Pedahohichni nauky»-Collection of scientific works of Taras Shevchenko Kremenets Regional Humanitarian and Pedagogical Institute. Series “Pedagogical Sciences”, 1 (3), 195-202 [in Ukrainian].

7. Marazha, I.O., \& Zhulkevych, I.V. (2021). Rol pedahohiky v klinichnii praktytsi likaria [The role of pedagogy in the clinical practice of the doctor]. Medychna osvitaMedical Education, 2, 94-99. DOI https://doi.org/10.11603/ me.2414-5998.2021.2.12058 [in Ukrainian].

8. Orel-Khalik, Yu.V. Formuvannia kultury profesiinoho spilkuvannia maibutnikh likariv zasobamy inozemnoi movy [Formation of communicative culture of future doctors by means of foreign language]. Retrieved from: www.nbuv. gov.ua/portal/.../P2312_59.pdf [in Ukrainian].

9. Semichenko, V.A. (1997). Puti povyisheniya izucheniya psihologii [Issue to study psychology]. Kyiv: Magistr-S [in Ukrainian].

10. Filonenko, M.M. (2008). Psykholohiia spilkuvannia : pidruchnyk [Psychology of communication: textbook]. Kyiv: Tsentr uchbovoi literatury [in Ukrainian].

11. Vorona, I.I., \& Kitura, H.Ya. (2021). Terminological vocabulary of communicative culture in the paradigm of foreign language competence. Medychna osvita - Medical Education, 1 (91), 98-105.

Електронна адреса для листування: voronai@tdmu.edu.ua 